


\title{
PROJETO BAIXIOS DE \\ VIADUTOS DA VIA EXPRESSA \\ LESTE-OESTE ${ }^{1}$
}

\author{
PROJECT UNDER VIADUCTS AT EAST-WEST \\ EXPRESSWAY
}

\author{
Carlos Teixeira ${ }^{2}$ \\ Flavio Agostini ${ }^{3}$ \\ Luciana Cajado ${ }^{4}$
}

\section{Resumo}

O artigo trata sobre áreas que pertencem ao setor público, um reservatório de terrenos ociosos sujeitos a ocupações pela população de baixa renda e mesmo por setores da economia formal. O objetivo básico do projeto "Baixios de Viadutos" é lançar um plano de programas (com fins de implantação real) para uma parcela específica dessas áreas ociosas nunca vistas como locais com potencial de ocupação planejada. Essas são as áreas lindeiras aos 12 viadutos e 3 passarelas de pedestres ao longo dos 15 quilômetros de extensão da Via Expressa Leste-Oeste, uma das principais vias arteriais da grande $\mathrm{BH}$ e que conecta o Município de Belo Horizonte ao Município de Betim.

Palavras-chave: Viadutos; Requalificação urbana; Políticas habitacionais; Direito à moradia; Sem-teto.

\begin{abstract}
The article discusses about areas that belong to the public sector, a reservoir of idle land subject to occupations by low-income population and even by sectors of the formal economy. The basic objective of the project "Under the Viaducts" is launching a program plan - with the purpose of real implementing - for a specific portion of these unused areas ever seen as potential sites of planned occupation. These are the areas bordering the twelve viaducts and three pedestrian walkways along the fifteen kilometers from the East-West Expressway, one of the main arterial roads of $\mathrm{BH}$ and that connects the city of Belo Horizonte at the municipality of Betim.
\end{abstract}

Keywords: viaducts, urban revitalization, housing policies, right housing, homeless 